BIOTROPIA No. 7, 1994: 1-11

\title{
BIOLOGICAL CONTROL OF DAMPING-OFF FUNGI OF AGOHO (CASUARINA EQUISETIFOLIA L.) USING ANTAGONISTIC BACTERIA
}

\author{
F.A. DELAPEÑA \\ Mariano Marcos State University, Batac, Ilocos Norte \\ Philippines 2906 \\ A.K. RAYMUNDO, E.P. MILITANTE, M.U. GARCIA and \\ L.U. DELACRUZ \\ University of the Philippines at Los Banos, College, Laguna \\ Philippines 4031
}

\begin{abstract}
A series of laboratory and nursery experiments were conducted specifically to determine the efficacy of 85 strains of Bacillus species and 15 actinomycetes against six fungal pathogens isolated from damped-off agoho. These damping-off fungi were: Fusarium oxysporum Schet., Rhizoctonia solani Kuhn., Phytophthora parasitica Dastur, Pythium debaryanum Hesse, and two unidentified pathogens temporarily designated as Unk 1 and Unk 2.

Preliminary test using the agar-plug technique revealed that 18 of the bacterial isolates could suppress two or more of the six damping-off fungi. Fusarium oxysporum was inhibited by 17 bacterial isolates, $R$. solani by 8 isolates, $P$. parasitica by 14 isolates and $P$. debaryanum by 15 isolates. The unidentified damping-off fungi Unk 1 and Unk 2 were inhibited by 13 and 9 isolates, respectively.

Further screening using the agar-diffusion method disclosed that 10 isolates were effective antagonists with Bacillus subtilis (Code No. R060), Bacillus sp. (Code No. R071), and Streptomyces sp. (Code No. R086) as the consistent and most effective inhibitors.

Application of the three most promising antagonistic bacteria as seed treatment showed that they effectively inhibited the growth of the damping-off fungi in the laboratory as exhibited by an increase in percent germination. Bacillus subtilis however, was not able to antagonize the effect of P. debaryanum in this particular experiment.

Seed germination and seedling survival were likewise improved with the application of the three most promising antagonistic bacteria as seed treatment. This was shown after three months under nursery conditions.

There were possible mechanisms of control by the antagonistic bacteria against the damping-off fungi. The mycelium and spores of the pathogenic fungus may have been attacked and parasitized by the antagonist when they were simultaneously grown in culture media. There must have been a competitive interaction between the two microorganisms. Any essential requirement of microorganisms can serve as potentially possible basis for competition.

Another was antibiosis which is an inhibitory effect exerted by an organism upon another organism through the production of antibiotic compounds. Moreover, several strains of bacteria are effective in lysing cell walls of pathogenic fungi under laboratory conditions. Lysis is often attributed to production of cell wall degrading enzymes like chitinase and gluconase that may hydrolyze major constituents of fungal cell walls.
\end{abstract}


Furthermore, several strains of bacteria are effective in lysing cell walls of pathogenic fungi under laboratory conditions. Lysis is often attributed to production of cell wall degrading enzymes like chitinase and glucanase that may hydrolyze major constituents of fungal cell walls. As demonstrated by Kapoor and Kar (1979), hyphae showed lysis in addition to thickening of hyphae as well as formation of chlamydospores in abundance as an effect of Bacillus sp. on F. oxysporum f. sp. lycopersici. Inhibitory substance diffused into the media may initiate fungal cell wall lysis.

Most bacteria are effective fast-growing colonizers which make such microorganisms efficient biological control agents of plant diseases. Seed treatment gave the antagonist the opportunity to be the first colonizer of the plant roots of the seedlings (Elad and Chet 1987) thus having an advantage for any competition for nutrients supplied by roots. Seed exudates probably occurred in the interaction between the antagonistic bacteria and damping-of $\mathrm{f}$ fungi in the root and is responsible at least to a degree for the observed biological control by introduced bacteria. Large populations of bacteria established on planting material and roots become a partial sink for nutrients in the rhizophere, thus reducing the amount of carbon and nitrogen available to stimulate sporulation of fungal pathogen or for subsequent colonization of the root (Weller 1988). In addition, cell wall degrading enzymes are activated by nutrient deprivation imposed by microbial activity.

Oospore germination by some damping-off fungi has already been shown to be affected by exogenous nutrients (Howell and Stipanovic 1980). Nutrients supplied by root exudates stimulate oospore germination in the rhizosphere. It therefore, appeared that bacteria may compete with germinating oospore for available carbon or nitrogen sources, and by eliminating these resources, the bacteria reduce the percentage of oospore germination. In addition, Elad and Chet (1987) stated that there was a significant positive correlation observed between inhibition of oospore germination and disease reduction by bacteria.

\section{CONCLUSION}

The promising antagonistic bacteria therefore, could reduce the incidence of damping-off disease of agoho. Its application as biological control agent could be a good substitute for soil fungicides. Although soil fumigation is very effective for the control of damping-off pathogens, it is very expensive, impractical and may create problems like environmental pollution and pathogen resistance. 
Biological control of damping-off fungi of agoho - F.A. Dela Pena et al.

\section{REFERENCES}

DAYAN, M.P. and V.O. SINOHIN. 1989. Diagnosing Forest Tree Diseases (Fungal). Ecosystem Research and Development Bureau, College, Laguna. 29 p.

DELA CRUZ, A. 1986. Microbial Antagonists of the Potato Soft-Rot Pathogen, Erwinia carotovora pv. carotovora (Jones) Bergey, Harrison, Breed, Hammer, and Hutton. (Unpublished MS Thesis, University of the Philippines at Los Banos, College, Laguna).

DICKSON, J.G. 1956. Diseases of Field Crops. Me. Graw Hill Book, Co., New York, 517 p.

ELAD, Y. and I. CHET. 1987. Possible role of competition for nutrients in biocontrol of Pythium damping-off by bacteria. Phytopathol. 1: 375-396.

GARRET, S.D. 1965. Toward biological control of soil-borne plant pathogens: 4-16. In: K.F. Barker and W.C. Snyder (eds.), Ecology of Soil-Borne Plant Pathogens-, Prelude to Biological Control. University of California Press, California.

HENIS, Y. and I. CHET. 1975. Microbiological control of plant pathogens. In: D. Perlman (ed.) Advances in Applied Microbiology. Vol. 19. Academic Press, New York. 332 p.

HENIS, Y. and M. IMBAR. 1968. Effect of Bacillus subtilis on growth and sclerotium formation by Rhizoctonia solani. Phytopathol. New York.

HOWELL, C.R. and R.D. STIPANOvIC. 1980. Suppression of Pythium ultimum induced damping-off of cotton seedlings by Pseudomonasfluorescens and antibiotic pyoluteorin. Phytopathol. 70: 712 - 715.

JONES, R.K. 1985. Fungicides for bedding plants. Bedding Plants Inc. News 16(2): 3-4.

KAPOOR, I.J. and B. KAR. 1989. Antagonism of Azotobacter and Bacillus to Fusarium oxysporum $\mathrm{f}$. sp. lycopersici. Indian Phytopathol. 42(3): 400-404.

LARSON, R. 1987. Growing concerns. Pest control: How much is enough. Marketletter 2: 5.

NATIONAL RESEARCH COUNCIL. 1984. Casuarinas: Nitrogen Fixing Trees for Adverse Sites. National Academy Press, Washington D.C. 118 p.

OLSEN, C.M. and K.F. BAKER. 1968. Selective heat treatment of soil and its effects on the inhibition of Rhizoctonia solani by Bacillus subtilis. Phytopathol. 58: 79-87.

RAYMUNDO, A.K., E.T. SERRANO, G.D. REYES and T.O. ZULAYBAR. 1985. Isolation and identification of antibiotic-producing Bacillus from the soil. Phil. Agr. 68: 393-402.

WELLER,D.M. 1988. Biological control of soilborne plant pathogens in the rhizosphere with bacteria. Ann. Rev. Phythopathol. 26:379-407. 
Pre-emptive colonization was also a possible mechanism of control. Seed treatment gave the antagonist the opportunity to be the first colonizers of the plant roots and moved along the roots of the seedlings thus having an advantage for any competition of nutrients. Most bacteria are effective fast-growing colonizers which make such microorganisms efficient biological control agents of plant diseases.

Key Words: Biological control. Fungal diseases, Casuarina equisetifolia, Antagonistic bacteria

\section{INTRODUCTION}

Agoho (Casuarina equisetifolia L.) is a good fuel wood species in scores of tropical countries like the Philippines. It has particularly been valuable for stabilizing sand dunes as it withstands salt sprays, thrives/grows in Infertile soil and is drought-tolerant (National Research Council 1984). These indispensable characteristics make it highly recommended for reforestation and afforestation purposes. Damping-off disease however, is the major threat in the production of sufficient and quality planting stocks.

Damping-off is a term applied to any disease that results in the decay of seeds in the soil before seedling emergence, or rapid rotting usually at the soil line of recently emerged seedlings (Dayan and Sinohin 1989). It is caused by a number of soil-inhabiting fungi that are facultative parasites and not specialized as to host. The ubiguity of damping-off fungi necessitates effective control measures because there are times when seedlings in the entire seedbed are wiped out resulting to shortage of supply for field planting. Chemical control is usually not feasible due to the expensive price of fungicides. Moreover, they can cause environmental pollution and may even induce pathogen resistance (Jones 1985; Larson 1987).

Biological control perhaps offers one of the best alternatives. As defined by Garret (1965), biological control is any condition or practice under which survival or activity of a pathogen is reduced through the agency of any organism (except man himself) with the result that there is a reduction in the incidence of the disease caused by the pathogen. One of the ways that biological control may operate to suppress pathogen is introduction of biocontrol agents or antagonists. It is for this purpose that a study on the biological control of damping-off fungi of agoho using antagonistic bacteria was conducted. Specifically, the study aimed to determine the efficacy of promising antagonistic bacteria in the laboratory and under nursery conditions. 
Biological control of damping-off fungi of agoho - F.A. Dela Pena et al.

\section{MATERIALS AND METHODS}

The antagonistic activity of 100 bacterial isolates consisting of 85 strains of Bacillus species and 15 actinomycetes was determined against six fungal pathogens isolated from damped-off agoho. The damping-off fungi were: Fusarium oxysporum Schet., Rhizoctonia solani Kuhn., Phytophthora parasitica Dastur, Pythium debaryanutn Hesse, and two unidentified pathogens temporarily designated as Unk 1 and Unk 2.

Preliminary screening using the agar-plug technique involved simultaneous inoculation of the pathogen (damping-off fungus) and the antagonist (bacterial isolate). Bacterial isolates showing good antagonistic activity were then subjected to the agar-diffusion method and further tested in the laboratory and under nursery conditions as seed treatment.

\section{Agar-Plug Technique}

The cell suspension of Bacillus species was prepared by growing the organism in tryptone glucose yeast extract agar (TGYA) in a flat bottle for 24-48 $\mathrm{hr}$ under room temperature. After incubation, the growth was flooded with sterile distilled water and then aseptically dislodged from the agar. The resulting suspension was adjusted to 0.30 optical density (OD) at $540 \mathrm{~nm}$ using a Spectronic 20 to have the de sired population of $10^{9}$ cells $/ \mathrm{ml}$ (Dela cruz 1986).

The cell suspension of actinomycete was prepared by growing the organism in yeast-malt extract broth (YMB) for $48-72 \mathrm{hr}$ on a shaker at room temperature. The broth culture was then pooled to make the necessary amount needed and homogenized using an osterizer for $5 \mathrm{~min}$. A $10 \%$ suspension was made by diluting $100 \mathrm{ml}$ of the prepared actinomycete suspension into $900 \mathrm{ml}$ sterile distilled water (Dela Cruz 1986).

Agar plugs were prepared by initially growing the damping-off fungus on potato dextrose agar (PDA) under room temperature for seven days or until sufficient growth was obtained. A sterile 1-cm-diameter cork borer was used to obtain the agar plugs from these culture plates.

The agar plugs inoculated on agar plates were initially prepared by plating $1 \mathrm{ml}$ of bacterial cell suspension on TGYA for Bacillus species and yeast-malt extract agar (YMA) for actinomycetes. Inoculation of the agar plugs was done in an upside-down position to provide a direct contact between the pathogen and the antagonist. The assay plates were incubated at room temperature for 3 to 5 days, after which growth of the pathogen was observed. This experiment utilized a Completely Randomized Design (CRD) with three replications. 


\section{Agar-Diffusion Method}

Cultures (24 to 48-hr-old) of the potential antagonistic bacteria were used to inoculate tryptone glucose yeast extract broth (TGYB) for Bacillus species and YMB for actinomycetes. These were then incubated at room temperature on a shaker. After $48 \mathrm{hr}$ (for Bacillus spp.) and $72 \mathrm{hr}$ (for actinomycetes) incubation, the broth cultures were centrifuged at $14000 \mathrm{rpm}, 0^{\circ} \mathrm{C}$, for $15 \mathrm{~min}$. The supernatant was used for the microbial assay.

One loopful of growth from 48-hr-old culture of the damping-off fungus was suspended in $2 \mathrm{ml}$ sterile distilled water, mixed and the suspension inoculated into $100 \mathrm{ml}$ PDA top agar. This was used to seed the PDA plates and then allowed to solidify (Raymundo et al. 1985).

Following the solidification of the top agar, four cup cylinders were positioned on the plate and these were then filled with $0.1 \mathrm{ml}$ of appropriate supernatant from each potential antagonist. After incubation for $48 \mathrm{hr}$ or until sufficient growth was obtained, the assay plates were examined and the diameter of zones of inhibition was measured. This experiment utilized a CRD with three replications and three subreplications. Significant values were further subjected to Duncan's Multiple Range Test (DMRT).

Antagonistic bacteria showing potential to control the damping-off fungi in the agar-diffusion method were further screened as seed treatment in the laboratory and under nursery conditions.

\section{Laboratory Experiment}

Newly prepared cell suspensions of the antagonistic bacteria were used to coat the agoho seeds by soaking for at least $15 \mathrm{~min}$. before sowing onto sterile germination plates lined with tissue paper. The germination plates were initially inoculated with $5 \mathrm{ml}$ fungal cell suspension prepared by suspending a loopful of growth of a 48-hr-old culture onto 100 $\mathrm{ml}$ sterile distilled water.

Twenty agoho seeds treated with the antagonistic bacteria were sown in each inoculated germination plate. Untreated seeds sown in an uninoculated germination plate served as the control. All seeds sown were disease-free and previously surface-sterilized. The plates were incubated at room temperature for 15 days. Watering was regulated using sterile distilled water. Seed germination and the occurrence of damping-off disease were regularly assessed. The experiment utilized a CRD with three replications. 
Biological control of damping-off fungi of agoho - F.A. Dda Pena et al.

\section{Nursery Experiment}

The promising antagonistic bacteria were further screened as seed treatment under nursery conditions. A newly prepared bacterial cell suspension corresponding to each treatment was used to coat the agoho seeds. This was done by soaking for at least 15 min. before sowing into a pot with naturally infested soil. Untreated seeds sown in naturally infested soil served as the control. Another treatment made use of untreated seeds sown in a soil medium subjected to sterilization in an autoclave for $1 \mathrm{hr}$ at $15 \mathrm{psi}$ for three consecutive days. There were 20 disease-free and previously surface-sterilized seeds sown in every pot.

Seed germination and the occurrence of damping-off disease were assessed. The percentage of survival of the seedlings was determined after three months when the study was terminated.

The experiment utilized a CRD with five replications. Significant values were further subjected to DMRT.

\section{RESULTS AND DISCUSSION}

In vitro assay of the antagonistic activity of the 100 bacterial isolates using the agar-plug technique revealed that only 18 inhibited two or more of the damping-off fungi of agoho (Table 1). Fusarium oxysporum was inhibited by 17 bacterial isolates, $R$. solani by 8 isolates, $P$. parasitica by 14 isolates, and $P$. debaryanum by 15 isolates. The unidentified damping-off fungi Unk 1 and Unk 2 were inhibited by 13 and 9 isolates, respectively. Of those that showed inhibitory effects, 15 belonged to the genus Bacillus while three were actinomycetes.

Further screening using the agar-diffusion method disclosed that 10 were promising antagonists with B. subiilis (Code No. R060), Bacillus sp. (Code No. R071), and Streptomyces sp. (Code No. R086) as the consistent and most effective inhibitors (Table 2). Some of the strains listed for inhibitory effects gave values below that of the reference antibiotic mycostatin $(200 \mathrm{ug} / \mathrm{ml})$ while others did not produce any inhibition zone, thus there was no antimicrobial activity observed.

Effect of the three promising antagonistic bacteria on percent germination of agoho seeds inoculated with the damping-off fungi in the laboratory is shown in Table 3 . The control which was not inoculated with any of the six pathogens gave the highest seed germination of $81.67 \%$. It was however, surpassed though not significantly different by seed treatment with Bacillus sp. (Code No. R071) against $P$. parasitica resulting to 83.33\%. Inoculation with any of the damping-off fungi and with no seed treatment with any antagonist gave the lowest percent germination. Bacillussubtilis (Code No. R060) however, was not able to antagonize 
the effect of P. debaryanum in this particular experiment. Application or treatment with $B$. subtilis may not have been of optimum concentration to affect an increase in percent germination of seeds inoculated with $P$. debaryanum. This could also be due to the fact that this pathogenic fungus is considered very virulent (Dickson 1956).

Under nursery conditions, the antagonists suppressed the growth of the damping-off fungi (Table 4 and Fig. 1). Seed treatments gave percent germination values of 74, 69 and 78 for B. subtilis, Bacillus sp., and Streptomyces sp., respectively. Seed coating with Streptomyces sp. gave a comparable value with untreated seeds sown in sterilized soil $(83 \%)$.

Table 1. Inhibitory effects of the bacterial isolates on growth of the damping-off fungi of agoho based on agar-plug technique ${ }^{\mathrm{a}}$

\begin{tabular}{|c|c|c|c|c|c|c|c|}
\hline \multirow{2}{*}{$\begin{array}{l}\text { Code }^{\mathrm{b}} \\
\text { Number }\end{array}$} & \multirow[t]{2}{*}{ Classification $^{\mathrm{c}}$} & \multicolumn{6}{|c|}{ Inhibitory effect $^{\mathrm{d}}$} \\
\hline & & F. oxysporum & R. solani & P. parasitica & P. debaryanum & Unk 1 & Unk 2 \\
\hline R013 & $\mathrm{B}$ & + & - & + & + & - & + \\
\hline ROM & B & - & + & - & - & + & + \\
\hline R059 & B & + & + & + & + & - & - \\
\hline R060 & B & + & + & + & + & + & + \\
\hline R063 & B & + & + & + & + & - & + \\
\hline R070 & B & + & + & - & + & + & - \\
\hline R071 & B & + & + & + & + & + & + \\
\hline R072 & B & + & - & + & + & + & - \\
\hline R073 & B & + & - & + & + & - & - \\
\hline R074 & B & + & - & + & + & + & - \\
\hline R075 & B & + & - & + & - & + & - \\
\hline R076 & B & + & - & + & + & - & + \\
\hline R078 & B & + & - & - & + & - & - \\
\hline R079 & B & + & - & - & + & - & - \\
\hline R080 & B & + & - & + & + & + & - \\
\hline R086 & A & + & + & + & + & + & + \\
\hline R095 & A & + & + & + & + & + & + \\
\hline R099 & A & + & - & + & - & + & + \\
\hline \multicolumn{8}{|c|}{ Total number of } \\
\hline Active is & lates $=18$ & 17 & 8 & 14 & 15 & 13 & 9 \\
\hline
\end{tabular}

\footnotetext{
${ }^{\mathrm{a}}$ Results based on three replications

${ }^{\mathrm{b}}$ Treatments with no antimicrobial activity against any of the six damping-off fungi are not listed

${ }^{\mathrm{c}}$ Either belonging to the genus Bacillus (B) or an actinomycete (A)

${ }^{\mathrm{d}}$ Positive sign ( + ) means with inhibitory effect: negative sign (-) means no inhibitory effect
} 
Biological control of damping-off fungi of agoho - F.A. Dela Pena et al.

Table 2. In vitro assay of the antagonistic activity of the different bacterial isolates against the damping-off fungi of agoho using agar-diffusion method

\begin{tabular}{|c|c|c|c|c|c|c|}
\hline \multirow{2}{*}{ Treatments $^{\mathrm{a}}$} & \multicolumn{6}{|c|}{$\begin{array}{c}\text { Inhibition zone }{ }^{\mathrm{b}} \\
\text { (mean diameter in } \mathrm{mm} \text { ) }\end{array}$} \\
\hline & F. oxysporum & $R$. solani & P.parasitica & P. debaryanum & Unk 1 & Unk 2 \\
\hline Control & $0 \mathrm{f}$ & $0 \mathrm{~d}$ & $0 \mathrm{~d}$ & $0 \mathrm{e}$ & $0 \mathrm{~d}$ & $0 \mathrm{e}$ \\
\hline R013 & $0 \mathrm{f}$ & $0 \quad \mathrm{~d}$ & $0 \mathrm{~d}$ & $0 \mathrm{e}$ & $11.97 \mathrm{c}$ & $0 \mathrm{e}$ \\
\hline R060 & $21.65 \mathrm{c}$ & $29.63 a$ & $27.05 \mathrm{a}$ & $9.31 b$ & $19.21 \mathrm{a}$ & $17.85 \mathrm{c}$ \\
\hline R071 & $29.22 b$ & $19.09 \mathrm{~b}$ & $10.06 \mathrm{a}$ & $11.16 \mathrm{a}$ & $14.30 \mathrm{~b}$ & $34.67 \mathrm{a}$ \\
\hline R072 & $0 \mathrm{f}$ & $0 \quad \mathrm{~d}$ & $9.89 \mathrm{c}$ & $0 \mathrm{e}$ & $0 \quad \mathrm{~d}$ & $0 \mathrm{e}$ \\
\hline R074 & $0 \mathrm{f}$ & $10.71 \mathrm{c}$ & $0 \mathrm{~d}$ & $0 \mathrm{e}$ & $\begin{array}{ll}0 & \mathrm{~d}\end{array}$ & $11.37 \mathrm{~d}$ \\
\hline R07S & $9.73 \mathrm{e}$ & $11.80 \mathrm{c}$ & $0 \mathrm{~d}$ & $0 \mathrm{e}$ & $11.20 \mathrm{c}$ & $10.21 d$ \\
\hline R078 & $9.62 \mathrm{e}$ & $0 \mathrm{~d}$ & $0 \mathrm{~d}$ & $0 \mathrm{e}$ & $\begin{array}{ll}0 & \mathrm{~d}\end{array}$ & $0 \quad \mathrm{a}$ \\
\hline R079 & $0 \mathrm{f}$ & $12.58 \mathrm{c}$ & $0 \mathrm{~d}$ & $0 \mathrm{e}$ & $0 \quad \mathrm{~d}$ & $0 \mathrm{e}$ \\
\hline R086 & $31.42 \mathrm{a}$ & $27.69 \mathrm{a}$ & $18.43 b$ & $0 \mathrm{e}$ & $14.56 \mathrm{~b}$ & $25.26 b$ \\
\hline R095 & $9.75 \mathrm{e}$ & $11.96 \mathrm{c}$ & $9.24 \mathrm{c}$ & $9.00 \mathrm{c}$ & $\begin{array}{ll}0 & \mathrm{~d}\end{array}$ & $11.04 \mathrm{~d}$ \\
\hline $\mathrm{m} 200^{\mathrm{d}}$ & $14.05 \mathrm{~d}$ & $12.64 \mathrm{c}$ & $9.43 c$ & $8.67 d$ & $11.84 \mathrm{c}$ & $11.96 \mathrm{~d}$ \\
\hline
\end{tabular}

a Treatments with no antimicrobial activity against any of the six damping-off fungi are not listed

${ }^{\mathrm{b}}$ Results based on three replications with three subreplications

${ }^{\mathrm{c}}$ Means with the same letter within the column are not significantly different at $1 \%$ level using DMRT

${ }^{d}$ Reference antibiotic mycostatin $(200 \mathrm{ug} / \mathrm{ml})$

Table 3. Effects of the promising antagonistic bacteria on percent germination of agoho inoculated with damping-off fungi under laboratory conditions

Treatments $\quad$ Percent germination (means)

\begin{tabular}{|c|c|c|c|c|c|c|}
\hline & F. oxysporum & R. solani & P. parasitica & P. debaryanum & Unk 1 & Unk 2 \\
\hline Control & $91.67 \mathrm{a}$ & $87.67 \mathrm{a}$ & $81.67 \mathrm{a}$ & $81.67 \mathrm{a}$ & $81.67 \mathrm{a}$ & $81.67 \mathrm{a}$ \\
\hline Pathogen alone & $18.33 d$ & $1.67 \mathrm{~b}$ & $38.33 \mathrm{c}$ & $0 \mathrm{~d}$ & $0 \mathrm{e}$ & $26.67 d$ \\
\hline Pathogen + R060 & $65.00 \mathrm{~b}$ & $68.33 \mathrm{a}$ & $66.67 \mathrm{~b}$ & $0 \mathrm{~d}$ & $71.67 \mathrm{~b}$ & $58.33 b$ \\
\hline Pathogen + R071 & $50.00 \mathrm{c}$ & $66.67 \mathrm{a}$ & $83.33 \mathrm{a}$ & $63.33 b$ & $60.00 \mathrm{c}$ & $41.67 \mathrm{c}$ \\
\hline Pathogen + R086 & $75.00 \mathrm{ab}$ & $76.67 \mathrm{a}$ & $61.67 \mathrm{~b}$ & $30.33 \mathrm{c}$ & $51.67 \mathrm{~d}$ & 71.67ab \\
\hline
\end{tabular}

Means with the same letter within the column are not significantly different at $1 \%$ level using DMRT

Furthermore, Table 4 and Fig. 1 show that percent survival of seedlings was increased by seed treatment with values of 94, 85, and 95 for B. subtilis, Bacillus sp. and Streptomyces sp., respectively. These were significantly different with the control (62\%). Seed coating with B. subtilis and Streptomyces sp. gave comparable values with untreated seeds sown in sterilized soil (99\%). 


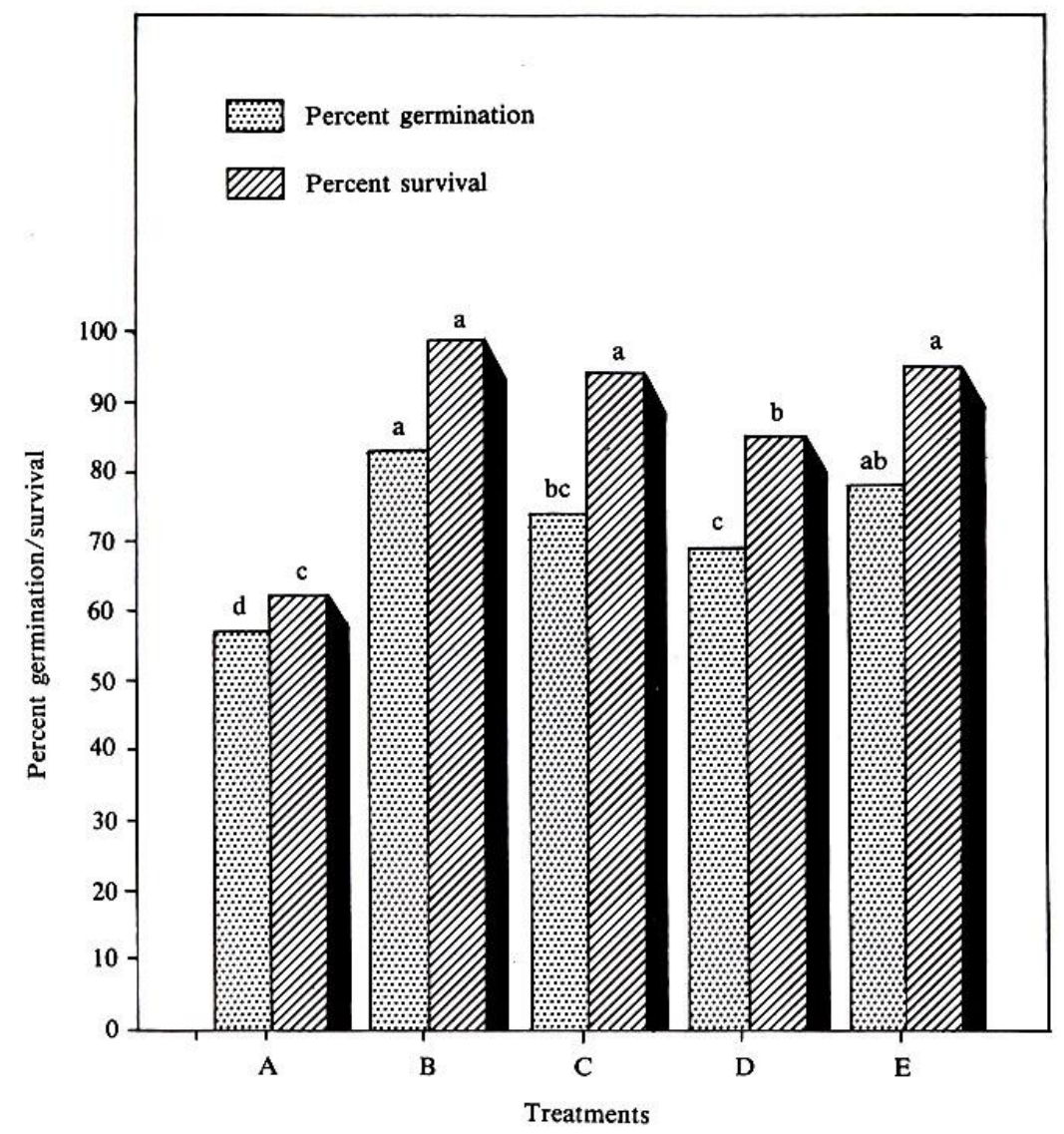
A - Untreated seeds sown in naturally infested soil
B - Untreated seeds sown in sterilized soil
C - B. subtilis treated sown in naturally infested soil
D - Bacillus sp. treated seeds sown in naturally infested soil
E - Streptomyces sp. treated seeds sown in naturally infested soil

Figure 1. Effects of the three promising antagonistic bacteria on percent germination and survival (after three months) of agoho under nursery conditions. Bars with the same fill marked with different letter(s) are not significantly different at the 5\% level using DMRT 
Biological control of damping-off fungi of agoho - F.A. Dda Pena et al.

Table 4. Effects of the three promising antagonistic bacteria on percent germination and survival (after three months) of agoho under nursery conditions

\begin{tabular}{ccc}
\hline \hline Treatments & Germination & Survival \\
\hline A & $57 \mathrm{~d}$ & $62 \mathrm{c}$ \\
B & $83 \mathrm{a}$ & $99 \mathrm{a}$ \\
C & $74 \mathrm{bc}$ & $94 \mathrm{a}$ \\
D & $69 \mathrm{c}$ & $85 \mathrm{~b}$ \\
E & $78 \mathrm{ab}$ & $95 \mathrm{a}$ \\
\hline
\end{tabular}

Means followed by a common letter are not significantly different at $5 \%$ level by DMRT.

Legend: A - Untreated seeds sown in naturally infested soil

B - Untreated seeds sown in sterilized soil

C - B. subtilis treated seeds sown in naturally infested soil

D - Bacillus sp. treated seeds sown in naturally infested soil

E - Streptomyces sp. treated seeds sown in naturally infested soil

Results of the assay methods revealed that a considerable number of Bacillus sp. and actinomycetes could inhibit the growth of damping-off fungi in culture. The mycelium and spores of the pathogenic fungi may have been attacked and parasitized by the antagonists when they were simultaneously grown in culture media utilizing the agar-plug technique. There must have been a competitive interaction between the two microorganisms as supported by studies of Henis and Chet (1975). Any essential requirement of microorganisms can serve as potentially possible basis for competition. Competition for nutrients between the antagonist and germinating spores of the pathogenic fungus could have taken place. Olsen and Baker (1968) added that B. subtilis which developed along the mycelial wall of $R$. solani apparently obtained nutrients either from wall components or contents leaking from senescent fungal cells.

In the agar-diffusion method, antibiosis which is an inhibitory effect exerted by an organism upon another organism through the production of antibiotic compounds may have likely occurred. The supernatant used in the assay demonstrated the possible role of antibiotics in biological control.

Moreover, most strains of $B$. subtilis or any other species of the genus Bacillus and actinomycetes produce a wide variety of antibiotics which inhibit filamentous fungi. Bacillus subtilis in particular, produces a subtilinlike antibiotic (Henis and Chet 1975) in addition to bulbiformin, mycosubtilin and bacillomycin (Henis and Inbar 1968) which have antifungal activity. Some of the antibiotics produced by such strains may be extracellular, diffusable in solid agar, and could inhibit the growth of fungal pathogens. 